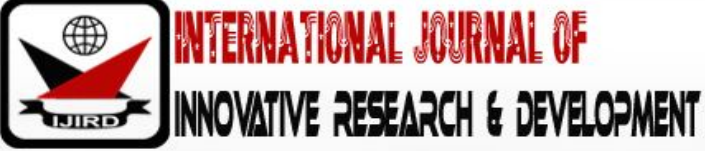

ISSN 2278 - 0211 (Online)

\section{Assess the Negative Implication of Road Construction Project on Property Investment on: A Case Study of Trans Amadi Industrial Layout Road, Nigeria}

\author{
Humphrey Chizi Tasie \\ Student, Department of Estate Management, Rivers state university, Port Harcourt, Nigeria \\ Dr. Chukwuemeka Ekenta \\ HOD, Department of Estate Management, Rivers State University, Port Harcourt, Nigeria
}

\begin{abstract}
:
This study aims at assessing the negative implication of road construction project on property investment in the specified section of Trans Amadi Industrial Layout Road, Port Harcourt, Rivers State, Nigeria. The objectives of the study are to ascertain the negative effects of road construction project on property investments. Examine the negative implications of road construction project on property investment. To identify the negative impact of road construction project on property investment values and to evaluate the negative implication of road construction project on investment values. The study utilizes the case study approach with quantitative method employed by the administration of structured questionnaires purposively on the selected 80 landlords, tenants, and estate surveyors operating and living in the road under study and out of the 80 selected respondents, 60 respondents duly complicated and returned their questionnaires all of which were found useful to the study. The primary data collected were collected, analysed and presented using frequency distribution tables, percentages, means scores and relative importance index (R11). Finally, the study findings reveal from the negative effects resulted from flooding that $50.0 \%$ of the respondent agreed that road construction causes flooding in the study areas, while $41.7 \%$ agreed that it cause degrees in rental values while $8.3 \%$ did not respond. It implies that the majority of the respondents agreed that road construction causes flooding in the neighbourhood resulting to decrease in rental values of properties. However, it is found that property market is not fully efficient regarding impending road construction which road dominates the extreme occurrence. The study recommends that government should take the issue of proper road construction, maintenance, and rehabilitation as a matter of proper road priority because these processes enhance property investments and property investment values.
\end{abstract}

Keywords: Road construction, property investment, property value

\section{Introduction}

Road construction project and property investment are very important in the physical and economic infrastructural development of cities and town all over the world and society. Investment property and values of land seem to be on the increase in the areas having road network increase and expansion, also increase slowly less rapidly in areas having no such development improvement. The rapid increase and the incessant increase in the property investment and land prices are very much expected in the cities or towns with road transport development and the continuous economic and population growth. (Goldberg, 1970).

Road construction is an infrastructural investment that is usually undertaking to improve accessibility at a regional or urban level and relief traffic stagnation and congestion. This is also synonymous to Trans-Amadi industrial layout road axis and to improve investment property in the neighborhood. However, the effect of road construction project, the road transportation development, roads or highways in particular, may have both positive and negative effects on property investment. Also, improved road accessibility may shift property investment upwards or downward due to bad construction without proper and adequate setting out, leveling, and study of road work which is above the natural ground level and without proper drainage resulting to flooding in the adjacent property investments or commercial properties and outlets.

Analyzing the effects of the various positive and negative externalities of the property investment relating to road construction project, may also be used in road construction evaluation, and assessing which externalities is most dominant and to what extent road construction and its implications affects property investment for future policy planning. The argument that the effects road construction and transportation infrastructure development have on property investment vary between investments depending on their geographical location, municipality affiliation and proximity to the investment property. Man, nations, regions and the world would be severally limited in property, investment or development without good road construction project investment or development without good road construction project which is a key factor for physical and economic growth (Oyesiku, 2002). 


\subsection{Statement of the Research Problem}

The research problem adduced in the road construction project always Trans Amadi Industrialroad includes a decline in the economic activities due to flooding/ erosion of the road, resulting to closure of business enterprises in the Trans Amadi Industrial road on real property investment. Also, includes loss of revenue on real property investment in Trans Amadi Industrial road due to noise/ vibration of the road and its environs. The inherent water/ flooding of the business, commercial, residential premise due to poor design of the road and high level of the road that led most of the premise to be far below the pavement and without drainage affected the properties along the two segmental areas of the study area.

\subsection{Objectives of the Study}

The paper outlines some objectives of the study which includes;

- To examine the negative bottle neck of road construction project on property investment.

- To ascertain the negative effects of road construction project on property values.

- To examine the negative implication of road construction project on rental investment.

- To identify the negative impact of road construction project on property investment values.

\section{Literature Review}

Road construction projects and its assessment on negative impaction on property investment has been a serious concern and matter to property investor, estate surveyors and values, individuals, cooperate organizations and to government. Road construction project according to the organization for economic co-operation and development (OECD) is defined as line of communication (travel way) using a stabilized base other than rails or air strips open to public traffic, primary for the use of road motor vehicles running on their own wheel "which includes bridges, tunnels supporting structures, junctions, crossings, interchanges, and toll roads but not cycle paths. In the urban areas construction of roads may diverge through a city or village and be named as streets serving a dual function urban space easement and route.

Man, nations, regions and the world would be severely limited in development without transportation, which is a key factor for physical economic growth (Oyesiku, 2002).

Road construction project and land use are interdependent. Indeed, findings of earlier studies reveals that compelling and consistent connections amongst them (Ewing and Cerveron, 2001; Polzin, 2004). According to Barley, Mokhtarian, and Little (2008), road construction project route is part of distinct development patterns or road network and mostly described by regular street patterns as an indispensable factor of human existence, development and civilization. Road construction project network are observed in terms of its components of accessibility, connectivity, traffic density, level services, compaction and density of particular roads. Level of service is a measure by which the quality of service on road construction devices or infrastructure is determined, and it is a holistic approach considering several factors regarded as measures of traffic density and congestion rather than overall speed of the journey (Mannering, Walter, and Scott, 2004). Access to major roads provide relative advantage consequence upon which commercial users locate to enjoy the advantages. Modern business industries, tracks and general activities depend on road transport and road transport infrastructure, with movements of goods and services from place to place becoming vital and inseparable aspects of global and urban economic survival. Development of various road construction modes have become pivotal to physical and economic development. Such modes include human porterages, railways, ropeways and cable ways, pipelines, inland waterways, sea, air, and road (Said and Shah, 2008). A number of factors affects property values which include intrinsic and extrinsic factor. The extrinsic factors include good road network and transport accessibility, increase in demand for let table space, location, condition of adjoining investment properties, measure to park and leisure, local and national economic conditions, or intrinsic factors are due to natural characteristic of the property which affect the city where the property is located. Intrinsic factor arises from within the nature of the property itself and relate to the physical attributes, including size of room, state of repair, decoration and facilities. Other attributes that increase or decrease the amount that users are willing and able to pay in an open market transaction include physical characteristic of the structure, change in taste and demand, effect of adjacent activities, economic activities, inflation and change in legislation. Transportation include physical characteristics of the structure, change in taste and demand, effect of adjacent activities, economic activities, inflation, and change in legislation.

The increase in demand for commercial property investment or business investment properties is affected by change in population, planning and development schemes, legislation, and availability of good road network make values of this properties to rise or decease (Olayiwola, Adeleye and Oduwaye, 2006). According to Mensah (2014), emphasis on transportation role in the economy to be more of wealth creation rather than wealth consumption. Its impact on the economy is made possible because it provides accessibility which in turn induces mobility. In the researcher view, the government needs to increase its commitment in the transportation sector as good road is indeed the life blood of every economy. The Negative effects may also result from an increase in traffic noise pollution, which has also been found to be a cause of reduction in the value of properties that are located along a newly developed high way (Kim, 2007; Nelson, 1982; Theebe, 2004, Wilhelmsson, 2000).

It is better known also that closer properties to road network are subject to transportation related externalities due to road construction project. (Carey, (2001). Most of these externalities' variables tend to affect property values in a spatial distributed arrangement. Loss of visual amenity, air and noise pollution are mostly the commonly discussed negative externalities. The actual focus of this review is to enunciate a solid background on negative externalities caused by the establishment of road construction. Project and how it impacts on Property investment in such close proximity to such road.

According to Kutz (2008), road construction transport infrastructure projects can, cause environmental and social costs. These environmental and social costs impacts identified and well known to cause these negative impacts and 
implications are noise, air pollution, Compulsory acquisition of lands and impacts on local biodiversity (Hanley, 2001). It is also noted, that all these implications normally prevail during road construction projects and during the operational period.

\subsection{Project}

A project is a unique venture with a beginning and an end, conducted by people to meet established goods within parameters of cost, schedule and quality (Buchanam and Boddy, 1992). A project is set of people and other resources temporary assembled to reach specified objective, normally with a fixed budget and with a fixed time period. Project are generally associated with product or procedures that are being done for the first time period. Project are generally associated with products or procedures that are being done for the first item or with known procedures that are being altered (Graham, 1985). All project evolves through a similar "life cycle" sequence during which there should be recognized start and finish points. In addition, the project objective may be defined in a number of ways, for example, financial, social and economic, the important point being that the goods are defined and the project is finite (APM, 1993).

\subsection{Negative Implications of Road Construction Project on Property Investments}

The negative implication of road construction project on property investment due to flooding as one of the externalities of the road construction projects includes:

- The defectiveness of aesthetic view of real property investment environments aspora.

- Stagnation of flood water resulting to mosquito breeding place leading to outbreak of diseases exposing the occupier of the investments, houses or business premises nearby to unsafe and uncomfortable living condition.

- Abandonment and deserting of property investments leading to reduction in the living standards of the people.

- Poorly constructed road becomes flooded, the subject properties like business premises, property investment or investment values become depreciated.

- Business investment premises and residential houses are contaminated which affects property investments rents, values of invested properties are depreciated and reduce in value and in demand for occupancy and leasing etc. According to Kutz (2008) otherwell documented negative externalities resulting from road construction projects infrastructure improvement includes:

Operations- related impacts and facility which includes;

- Pollutant emissions,

- Noise,

- Vibration,

- Visual/aesthetics

- Community cohesion and in the facility-related impacts implication includes;

- water/ flood plains/ erosions

- Community cohesion/ cultural equity/ environmental justice

- Hazardous materials.

It is well sourced and recorded that the above are negative implication and externalities of road construction project on property investment.

\subsection{Real Property}

Real property, is defined as land, buildings and other improvements thereon and the legal rights relating to the asset, Ekenta, (2010). This definition is somewhat confusing as there is always a distinction between real property and real estate, though both terms are sometimes used interchangeably in real estate professional literature and practice. Real property is defined as only the interest, benefits and rights inherent in the ownership of real estate, while real estate is defined as only the physical land and with the improvement thereon, Schram, (2012). This distinction clarifies that real property cannot be both land and rights and that is the reason why most appraises are concerned in the interest subsisting in the property than the property perse.

Real property in any of its investment sector has the characteristics which are distributable from other investment, and to this Kalu, (2001) identified the characteristics to include; heterogeneity, risk and indivisibility. Others are; high cost of transfer; holding cost; income and capital growth; imperfect knowledge; perpetuity; and leverage or gearing. Real property differs from private property, which refers to things owned by an individual regardless of whether he is using them and has a right to prevent others from using what he does not use or has no intention of using. Real estate or immoveable property is a legal term that encompasses land together with anything permanently affixed to it. Real estate (immoveable property) is synonymous with real property otherwise called realty, in contrast with personal property (also sometimes called chattel).

\subsection{Investment}

The word "investment" represents different things to various people; Kalu (2001) define investment as the placing of capital at risk in return for a reward or the giving up of a capital sum in exchange for benefits to be received in future in the form of regular income flow and/ or capital appreciation. This definition presupposes that even though an investor usually undertakes risks, he would refuse to take a risk merely for the sake of it. According to Bodie, Kane and Marcus (1998) the attribute of investment is that you sacrifice something of value now expecting to benefit from the sacrifice later. From the forgoing Ekenta, (2014) opined that an investment can then be said to be the utilization of money or other valuable resources in such a way as to guarantee a regular flow over a period of time or the application and/ or the recouping of a specific lump sum on a future date in consideration for the utilized resources and risk taken. 


\subsection{Real Property Investment}

Real property investment is distinct from financial investment. It is distinct from financial investment in several ways and it is also limited in product. Ekenta, (2009) defined real property investment as the application of a capital sum in land and any permanent structures or improvement that are permanently attached to the land in expectation of a return either in the form of a recurring income or in the form of gain due to an appreciation in value, or both. Investment in real property is the nature of the receipt of total returns comparing income, return and capital appreciation return annually. Thorncroft (1976) stated that financial investment in real property involves acquiring land and building in order to derive from them rents or other annual income. Thorcroft, explained that investment in real property estate is comparable to other types of investments in the sense that investments such as the purchase of stock and shares are comparatively simple to analysis in terms of yields on capital and easy to compare with other opportunities that may exist for the investment.

According to Horne (1980), the riskiness of an investment proposal is the variability of its possible return. While Ajayi (1998) defined risk as the level of probability that a required return measure in terms of capital value and income will be achieved.

\section{Research Methodology}

Case study design or approach was adopted which involves the administration of questionnaires to the target population so as to actually pick or select or get necessary information for the study. The target population for the primary data Comprises tenants, estate surveyor's residential property and commercial property owners and landlords in the study area. The entire questionnaire was distributed randomly to the tenants, landlords, estate surveyor and property owners which numbered 80 questionnaires in all; but out of which 60 rating $(75.0 \%)$ was retrieved and applied for the study analysis. The presentation and analysis of data adopted descriptive frequency, means and percentage measures as well as the statistical package for social sciences (SPSS). Further applied was the relative importance index (RII) that was utilized in ranking some negative contribution of road construction project variables based on the importance noted to each by the respondents.

According to Lim and Alum (1995) RII is calculate by the forumular:

$$
R I I=\left(\frac{\left(I N_{2}+2 N_{2}+3 N_{3}+5 N_{5}\right)}{5 N}\right)
$$

Where:

RII $=$ Relative Importance Index

$\mathrm{N}_{1} \quad=\quad$ Number of respondents that answered not very important (NVIMP)

$\mathrm{N}_{2} \quad=\quad$ Number respondent that answered not important (NIMP)

$\mathrm{N}_{3}=\quad$ Number of respondents that answered important (IMP)

$\mathrm{N}_{4} \quad=\quad$ Number of respondents that answered very important (VIMP)

$\mathrm{N}_{5}=\quad$ Number of respondents that answered very important (VVIMP)

$\mathrm{N}=$ Total number of respondents

\subsection{The Study Area}

The Trans-Amadi industrial layout road is a major road tran-versing from Garrison round about junction to zoo and domiciled in Port Harcourt City Local Government Area of Rivers State and is geographically located within the Niger Delta Region of Nigeria. It has a total length of 4.6km (field survey, 2017) from Garrison Junction to zoo and withan area of $15,000 \mathrm{~m}^{2}$. The road leads to the major industrial base of the state and has boundaries with Orogbum and Elekahia Communities by the left and Nkpogu and Oginigba Communities by the right on the entire stretch of the road to zoo. The area benefit from moderately hot climate due to the geographical location, and due to the geographical location, the area is characterized by heavy rainfall from months of April to October yearly with high temperature all the year with relatively constant humidity. The road generally is in lowland having average elevation between 20 and $30 \mathrm{~m}$ above sea level. The soil in the area of the road is naturally very sandy or sandy loam and is underlainby impervious layer pan and it is constantly leached because of the magnitude of the rainfall usually experienced in the area that is properly drained with salt water andfresh water. The constant rainfall and water flows in the study area caused the flooding usually experienced every particular year. 


\section{Data Analysis Results and Discussions}

\begin{tabular}{|c|c|c|c|c|c|c|c|c|}
\hline Negative & \multicolumn{5}{|c|}{ WEIGHT (N = 60) } & TWN & RII & Ranking \\
\cline { 2 - 10 } Contribution & NVIMP & NIMP & IMP & VIMP & VIIMP & & Values & \\
\hline Damage to property & 0 & 0 & 15 & 160 & 75 & 250 & 0.83 & $1^{\text {st }}$ \\
\hline $\begin{array}{c}\text { Sales price of property } \\
\text { decreases }\end{array}$ & 0 & 12 & 33 & 100 & 90 & 235 & 0.78 & $2^{\text {nd }}$ \\
\hline $\begin{array}{c}\text { Added value to repairs } \\
\text { and renovation are } \\
\text { perceived }\end{array}$ & 0 & 20 & 30 & 104 & 75 & 229 & 0.76 & $3^{\text {rd }}$ \\
\hline $\begin{array}{c}\text { Reduced supply and } \\
\text { demand for properties }\end{array}$ & 5 & 8 & 57 & 80 & 80 & 230 & 0.75 & $4^{\text {th }}$ \\
\hline $\begin{array}{c}\text { Abandoned houses } \\
\text { serving as continual } \\
\text { visual reminder of } \\
\text { damage }\end{array}$ & 0 & 18 & 48 & 88 & 65 & 219 & 0.73 & $5^{\text {th }}$ \\
\hline
\end{tabular}

Table 1: Negative Contribution of Road Construction Project on Property Value Due to Flooding Source: Author field Survey, 2017

The results in table 1 shows and confirms that identified important negative contribution of road construction project, due to flooding; damage to property, sales of property decrease, added values to repair and renovations are perceived, reduced supply and demand for properties, abandoned houses, serving an a continues reminder of damage. It further reveals and confirms that damage to property was the most adverse negative contribution of road contribution project on property investment values due to flooding and ranked $1^{\text {st }}$ with $(\mathrm{R} 11$ value $=0.8333)$ amongst the identified negativecontribution of road construction project on property investment values due to flooding include sales of property decrease and ranked $2^{\text {nd }}$ with (R11 value $=0.7833$ ). Added values to repair and renovation are perceived and identified as another essential contribution and ranked $3^{\text {rd }}$ with (R11 value $\left.=0.7667\right)$.

Abandoned houses was also identified as negative contribution project on property investment values ranked $5^{\text {th }}$ with $(\mathrm{R} 11$ value $=0.7300)$ serving as continua reminder of damage ranked the least with (R11 value $=0.7133$ ). The findings on negative contribution of road construction project due to flooding on property investment values are amongst the possible targets to be checked and solution preferred for road construction project to avert flooding in the study areas for real estate investment in the two segmented sections of the study area.

The result in table 2 indicate and confirm he impacts of road construction project on property investment values an increase in the remaining life period of properties, increase in the amount of rent, reduction life.

\begin{tabular}{|c|c|c|c|c|c|c|c|c|}
\hline \multirow{2}{*}{ Impact of Road Construction Project } & \multicolumn{9}{|c|}{ Weight (N = 60) } & TWN & RII & \multirow{2}{*}{ Ranking } \\
\cline { 2 - 9 } & NVIMP & NIMP & IMP & VIMP & VVIMP & & Values & \\
\cline { 2 - 9 } & 1 & 2 & 3 & 4 & 5 & & & \\
\hline Pollutant Emission & 2 & 9 & 15 & 140 & 75 & 241 & 0.80 & $1^{\text {st }}$ \\
\hline Noise & 4 & 18 & 36 & 88 & 75 & 221 & 0.74 & $2^{\text {nd }}$ \\
\hline Vibration & 3 & 16 & 30 & 100 & 70 & 218 & 0.72 & $3^{\text {rd }}$ \\
\hline Visual/aesthetics & 6 & 8 & 54 & 80 & 60 & 208 & 0.69 & $4^{\text {th }}$ \\
\hline Community cohesion & 5 & 20 & 45 & 80 & 50 & 200 & 0.66 & $5^{\text {th }}$ \\
\hline
\end{tabular}

Table 2: Implication of Road Construction Project on Property Investment Values Source: Authors' Field Survey, 2017

The result in table 2 indicates a further investigation on the implication of road construction project on property investment and confirm the implication of road construction project investment values as pollutant emissions, noise, vibrations, visual aesthetics and community cohesion. The table further confirms and reveal that pollutant emissions are one of important of road construction project implication on property investment values and ranked 1 st with (RII value $=0.8033$ ) and also ranked $2^{\text {nd }}$ was noise that affect property values with (RII value $=0.7400$ ). Amongst the implications of road construction project on project investment values is vibration with (RII value $=0.7266$ ) ranking 3rdfurthermore, visual/ aesthetics for road construction project implication ranked $4^{\text {th }}$ with $(\mathrm{RII}$ value $=0.6933)$ and also identified another essential factor and implication of road construction project on property investment value is community cohesion ranked least with ( $\mathrm{RII}$ value $=0.6666$ ).

The finding reveals as confirmed from the study that the identified implication of road construction project on property investment values are the various variables and impacts associated with the implication of road construction project as it reduces the cost of investment values and property investment occupation for real estate investment in the study area.

\section{Conclusion and Recommendation}

This study has revealed that road construction project has negative contribution and positive impact contribution property investment values in encouraging real property investment, which in turn will enhance real estate, property and 
investment proliferations in the study area. Hence road construction project be properly handling with all the necessary studies carried out to avoid bad layout of road leading to negative construction that will deter real estate development investment.

\section{Recommendation}

Based on the research findings and conclusions, the following adduce recommendations are hereby provided in the study area towards forestalling the implication of road construction project. On property investment considering the negative implication of road construction project on property investment. It is therefore recommended that;

- There is the need for government to harness development potential and the speedily completion of road construction project as to reduce time and waste of financial resources spent on property management and maintenance.

- Government should take construction, maintenance and roads rehabilitations as a matter of greater important because landed property is an indicator of the wealth of the nation and values and their values can be enhanced through the provision of good roads.

- Government should include drainage facilities in all road project to devoid of flooding and increase funding for road construction, maintenance and arbitration because improving accessibility through road construction projects will enhance property values and encourages more development and investment.

Widening of the drainage system within the study area and subsequent desilting of the existing drainage and the construction of new and well designed and large drainage construction should be taken into consideration the peculiarity of low-lying nature of soil strata in Trans-Amadi.

- Government should ensure that road construction project does not cause community cushion and visual, aesthetics of the property, investment to avoid less demand for property.

\section{References}

i. Amp, (1993) Body of knowledge (Revised) Association of Project Managers.

ii. Ayai, C. A. (1998). Property Investment Valuation Analysis. Ibadan: De-Ayo Publications. International Journal of Business and Law Research 4(1):56-62, Jan -March, 2016.

iii. Bailey, L; Mokhtarian, P. L; Little A. (2008). The Broader connection between public transportation,Energy conservation and Green House Gas Reduction. Report prepared as part of TCRP Project J-II/Task3 transit Cooperative Research program, transportation research Board submitted to American Public Transportation. Association in http:/ / www.apta.com/ research/info/ onlin/ lane.une.ifm\#i, accessed 17 April, 2008.

iv. Bodie, Z; Kane, A and Marcus, A.J (1998) Essential of Investment. New York: Irwin McGrawhill.

v. Carey, J. (2001). Impact of Highway Property Values: Case Study of the Superstition Freeway Corridor. (A. D. O Transportation, ed).

vi. Ekenta, C. (2014). Analysis of Socio-Economic Impacts of Nigerian Land Reform of 1978 on Real Estate Investment in Rivers State. International Journal of Business and Law Research 4 (1): 56-62, Jan- March, 2016.

vii. $\quad$ Ekenta, C. (2016). Application of Capital Asset Pricing Model (CAPM) on Real Property Investment in Nigeria. International Journal of Business and Law Research 4(1): 56-62, Jan- March, 2016.

viii. Ewing, R and Cerveron, R. (2001). Travel and the Built Environment: A Synthesis Transportation research 1780, Washington, D. C: TRB, National Research Council.

ix. $\quad$ Goldberg, M. A. (1970). Transportation, Urban land values and Rents: A synthesis Land Economics 46(2) 153-162.

x. $\quad$ Hanley, N. (2001) "Introduction to Environmental Economics" I/ Ed Oxford University Press.

xi. Horne, V. (1980) Founding Family Controlled Forms: Performance, Risk and Value: Journal of Small business Management 3pp 17-24.

xii. Kautz, M. ed. (2008) “Environmentally Conscious Transportation”, Vol. 1 PP. 1-350. New Jersey, John Wiley and Sons, Inc.

xiii. Kalu, I. U (2001). Property Valuation and Appraisal; Owerri, bon Publication,.

xiv. Lim, E. C and Alum, J. (1995). Construction productivity: Issues encountered by Contractors in singapore. International Journal of Project Management. 13(1): 51-58.

xv. Levkovich, O. Rouwendal, J. and Van Marwijk, R. Transportation (2016). The Effect of Highway Development on Housing Prices: Netherlands, Springer Publisher: ISSN;0049-4488;EISSN:1572-9435.Serial URL:http:/ / link.springer.com/ Journal/11116. Journal of the National Academics of Sciences Engineering Medicine.

xvi. $\quad$ Mannering, F. L; Watter P; Kilareski;m Scotts. S. Washburn (2004). Principles of Highway Engineering and Traffic Analysis. 3rd ed. NJ: John Wiley and Sons; 170-219.

xvii. Mensah E; (2014), The Role of Road Transport in Economic Development PBBOK Project Management Institute, 2008, P. 442.

xviii. $\quad$ Mike, F and Laurie K, (2005). Project management, Bedford Row, London, Thomson Learning.

xix. Olayiwola, L. M; Adeleye, O. A; and Oduwaye, A. O.(2006) Spatial variation in Residential Land Value Determination in Lagos Nigeria. Paper presented at the international conference in promoting land administration and good governance 5th FIG regional conference Accra, Ghana, March, 8-11, 2006.

xx. Oyesiku, O. O. (2003) From Tomb to Tomb 24th Inaugural Lecture Olabisi (Onabanjo University on 27th August 2002 Ago- Iwoye: Olabisi Onabanjo University Press. 
xxi. $\quad$ Prasad, N. Clevo, W \& Tim, R (2016) Impacts of Major Roads on Property Values: An Analysis of an Existing and Proposed Road Corridor Project. Prasad, N. Clevo, W \& Tim, R (2016) School of Economic and Finance, Faculty of Business, Queensland University of Technology, GPO Box 2434, Brisbane Old 4001, Australis.

xxii. Polzin, S. E (2004) Relationship between Land use, Urban form and Vehicle Miless of Travel: The state of knowledge and Implication for Transportation Planning. University of South Floria, Tamoa; Flordia Deplantant of Transportation; Federal Highway Administration in http://www.cutr.usf.edu/pubs/tram-lu\%20 white\% 20paper\%20fund.pdf.

xxiii. $\quad$ Schram,J.Jr (2012). Real Estate Appraisal. Sixth Edition. U.S.A Rockwell Publishing

xxiv. Said, M. N, and Shah, M. Z. (2008) GIS as a Supporting Tool in the Establishment of Land Use Road Density Model in www. GIS development. Net.

xxv. Thorncroft, M. (1976). Principle of Estate Management, London. Estate Gazette, Journal of Scientific Research, 2016.

xxvi. $\quad$ Trans-Amadi Industrial layout (PH) Wikimapia. Retrieved 2014-8-18.

xxvii. Wyatt, P. (1997). The Development of a GIS Based Property Information for Real Estate Valuation. International Journal of formation Science II(5), 435-450. 